\title{
Mães libertas, filhos escravos: desafios femininos nas últimas décadas da escravidão em São Paulo
}

Freed Mothers, Enslaved Children: Cendred Challenges in the Last Decades of Slavery (São Paulo, Brazil)

Marília B. A. Ariza * 1

\section{Resumo}

Este artigo aborda uma face ainda pouco visitada das disputas por liberdade nas décadas finais da escravidão no Brasil imperial, qual seja a das disputas de mulheres libertas pela emancipação de seus filhos. A partir da análise de autos judiciais produzidos em São Paulo, sobretudo nos anos 1880, investiga tais disputas destacando práticas de negociação e resistência empreendidas por mães libertas de filhos ainda escravizados ou ingênuos; ao mesmo tempo, sublinha as muitas barreiras que se impunham à consecução de projetos familiares de emancipação liderados por essas mulheres. Assim, busca compreender a maternidade como experiência definidora de desafios especificamente femininos na busca por liberdade.

Palavras-chave: maternidade; escravidão; mulheres libertas; emancipação; trabalho.

\section{Abstract}

This paper addresses the challenges of freed women pursuing their children's emancipation over the last decades of Brazilian slavery, a topic that requires closer attention from historiography. Based on the analysis of judicial documents produced in the city of São Paulo, mostly during the 1880 s, it intends to investigate family emancipation projects headed by mothers of enslaved children, highlighting social practices of negotiation and resistance. At the same time, it considers the many obstacles encountered by these women on the way of their families to freedom. Thus, the paper aims to consider motherhood as a defining experience that sets specific challenges to women coming out of slavery and their children.

Keywords: motherhood; slavery; freed women; emancipation; labor.

\footnotetext{
* Doutora em História Social pela Universidade de São Paulo (USP), Programa de Pós-Graduação em História Social. São Paulo, SP, Brasil. mbaariza@gmail.com <https://orcid.org/0000-0002-6199-2344>
} 
Maria era uma entre tantas mulheres na cidade de São Paulo que, nos idos de 1870, após adquirir a própria alforria amealhando pecúlios ou assumindo longos compromissos de prestação de serviços, lançava-se a mais uma empreitada num longo e tortuoso caminho rumo à liberdade: para completar seu projeto de emancipação, precisava ainda libertar seu filho, Paulo, de cerca de 10 anos de idade, escravizado na mesma capital a José Gonçalves da Cunha.

Para manumitir Paulo, mobilizava esforços variados formando nova poupança, arranjando-se múltiplos empréstimos e uma fiadora e comprometendo-se, ao fim e ao cabo, com uma dívida nada módica de um conto e quinhentos mil réis, a serem pagos em um ano. ${ }^{2} \mathrm{~A}$ vultuosa soma corresponderia a um compromisso mensal com parcelas de 125 mil réis, valor muito superior àquele atribuído aos salários de mulheres libertas empregadas nos serviços domésticos na cidade, no fim do século XIX. ${ }^{3}$ Pode-se imaginar que, a tais parcelas, somar-se-iam ainda as despesas necessárias para a subsistência de Maria e sua família, talvez formada por mais filhos e parentes. Quais eram as chances de que pudesse arcar com os pesados custos da manumissão do filho sem se ver, afinal, engajada em um contrato de locação de serviços que, como tantos outros realizados na cidade e alhures àquela época, recrutava serviços de homens e mulheres libertos relegando-os a condições de dependência e experiências precárias de liberdade? ${ }^{4}$

Tornar-se livre era certamente uma tarefa em muitos sentidos custosa para qualquer sujeito escravizado; para as mulheres, o projeto compreendia adicionalmente imposições específicas da maternidade que têm escapado até o momento à análise mais cuidadosa da historiografia nacional..$^{5}$ Exemplos dessa dimensão algo desconhecida dos embates pela liberdade surgem indiscreta e insistentemente em autos judiciais e registros notariais, trazendo a lume a dimensão familiar de projetos femininos de emancipação e demonstrando, entre outras coisas, que muito frequentemente mulheres manumitiam-se primeiro para então, em condições um pouco mais confortáveis de acessar a Justiça ou formar poupanças, pleitear a alforria dos filhos. ${ }^{6}$

Exemplos dessa dinâmica pululam nos registros oficiais produzidos na cidade de São Paulo nas décadas finais da escravidão. Foi o caso de Brazilina, "cozinheira preta" manumitida pelo Fundo de Emancipação, que, em 1886, pleiteava a classificação junto à mesma instituição de seus filhos Thereza, Ignez e Victor, com idades entre 11 e 17 anos. ${ }^{7}$ No mesmo ano, a liberta Pulcheria, mãe de três filhos que seguiam vivendo em casa de seu ex-senhor Antonio Correa da Silva - sendo dois ingênuos, de 8 e 11 anos de idade -, solicitava ao Juízo a interposição de uma ação de liberdade por arbitramento em favor deles. 
A remissão dos serviços dos ingênuos em poder dos senhores ou ex-senhores, de fato, era prevista pela Lei 2.040 de 1871, ou Lei do Ventre Livre, contanto que suas mães se tornassem libertas antes de os filhos atingirem 8 anos de idade. Aproveitando-se desse dispositivo, Pulcheria amealhara a soma de 200 mil réis que peticionava serem depositados junto à Tesouraria da Fazenda, de modo a iniciar-se o processo de emancipação dos filhos. Outro era o caso da liberta Benedicta Maria da Conceição, cujo filho Antonio, contando 19 anos em 1887, não poderia usufruir as prerrogativas dos nascidos de ventre livre. No intuito de auxiliá-lo a forrar-se no futuro, Benedicta procurava constituir um modesto pecúlio de 150 mil réis, depositados em caderneta de poupança em nome de Antonio. ${ }^{8}$

Chama a atenção, na reunião desses breves exemplos de financiamento da alforria de mães e filhos, o caráter essencial assumido pelo trabalho árduo, a habilidade de acumular pequenas economias e arranjar-se crédito nos projetos de emancipação femininos e familiares. De fato, diversos estudos sobre alforria têm, há algum tempo, indicado a prevalência de mulheres entre os cativos beneficiados por manumissões, fossem elas conquistadas em ajustes incondicionais, que cumpriam o papel simbólico de atestar a benevolência senhorial, ou condicionais, associados à prestação de serviços ou a indenizações monetizadas. ${ }^{9}$ Não obstante, certo olhar historiográfico que identifica a manumissão de mulheres escravizadas e seus filhos a arranjos de natureza íntimo-sexual entre cativas e senhores, reconhecidamente legatário de narrativas sobre a lubricidade da mulher negra e da mestiçagem brasileira, mostra-se ativo ainda nos dias de hoje, desdenhando a importância da capacidade de trabalho e de improviso de modos de vida entre cativas e libertas. ${ }^{10}$

$\mathrm{Na}$ contramão dessas interpretações, os registros aqui discutidos atestam que o trabalho árduo e o investimento diuturno na formação de poupanças ocuparam papel central em alentados projetos de emancipação liderados por mulheres escravizadas e com filhos. Iniciá-los pela manumissão materna era uma opção estratégica que levava em consideração os amplos esforços necessários para a aquisição ou conquista judicial de diversas alforrias. Embora arquitetados por mulheres que compreendiam as brechas judiciais e as práticas sociais que poderiam mobilizar, assim como bem conheciam as limitações materiais e o reproche moral próprios de sua condição de escravizadas e libertas, esses projetos ampliados de emancipação não se mostravam empreendimentos de fácil execução, como bem demonstra o caso de Lucrecia, "parda forra". Representada por Lins de Vasconcellos, insigne advogado e filantropo paulista, Lucrecia submetia, em 1883, uma petição ao Juízo na qual informava que 
com fundo firmado com o labor próprio, adquiriu trezentos mil reis que confiou ao Sr. Antonio Bento de Souza e Castro para libertar a menor Margarida filha della supplicante e escrava do Major João Antonio Dias. Acontece que alem dessa quantia tem a filha da supplicante mais 200 mil reis que lhe doou Carlos Augusto Borba, e com a qual se pediu deposito da menor para libertar-se por arbitramento. Feito o deposito, o senhor da filha da supplicante libertou-a sem condição, mas pretende ficar com Ella em seu poder, o que será um segundo e pior captiveiro do que o primeiro. ${ }^{11}$

Tendo em sua causa, além de Lins de Vasconcellos, o apoio do famoso abolicionista Antonio Bento, que se tornara guardião do pecúlio por ela acumulado, Lucrecia contava ainda com uma doação que somada às suas próprias economias perfazia a indenização de 500 mil réis oferecida pela alforria de Margarida. Ressaltando o esforço empenhado na poupança que fizera, a petição em nome de Lucrecia reforçava sua capacidade de "por seu trabalho educar sua filha por quem já fez sacrifícios de economizar aqueles 300 mil reis”. A despeito de tal abnegação e compromisso, contudo, João Antonio Dias não parecia disposto a abrir mão dos serviços da menina. O "segundo cativeiro" a que se referia a petição que o acusava de aceitar o depósito do pecúlio, mas não libertar Margarida, correspondia, precisamente, a seu intuito de tutelá-la e contratá-la à soldada:

Diz o Tenente Coronel Joaquim Antônio Dias que sendo intimado hontem ... para o depósito da menor Margarida, de quatorze annos que requereu alforria por pecúlio, e como o supplicante já tivesse resolvido libertal-a, vem declarar a Vossa Senhoria que concede-lhe a liberdade gratuitamente, sendo o pecúlio recolhido ao cofre dos orphãos em beneficio da mesma menor, requerendo a Vossa Senhoria que seja nomeado tutor à mesma menor, e sendo esta dada à soldada na forma da lei para evitar que seja mantida em companhia de sua mãe que não pode de sua educação.

Sublinhando a incapacidade materna de Lucrecia, Dias prontamente oferecia-se como alternativa adequada aos melhores interesses da menor, propondo-se a assumir os encargos de seu tutor e contratante. Reforçavam o caráter pretensamente desinteressado e caridoso de sua proposta a concessão da alforria gratuita a Margarida, bem como a transformação do pecúlio amealhado por sua mãe em poupança a beneficiá-la futuramente. Nas entrelinhas de seu discurso, porém, lê-se claramente que a manumissão oferecida à filha de Lucrecia nada tinha de efetivamente incondicional. Libertando-a e em 
seguida engajando-a como tutelada, Dias teria poder sobre a menor até que ela completasse 21 anos, sem que sua mãe ou quaisquer abolicionistas seus defensores pudessem recorrer à justiça para emancipá-la - uma vez alçada à liberdade formal, estaria submetida às normas que regiam a tutela dos menores de idade, e estas garantiam amplo espaço para a apropriação da mão de obra de crianças e jovens livres e pobres, filhos de mães supostamente inadequadas. ${ }^{12}$

O amplo emprego de tutelas e contratos de soldada como mecanismo de arregimentação compulsória do trabalho de crianças empobrecidas não era, certamente, prerrogativa da classe senhorial paulistana. Diversos estudos têm, há algum tempo, demonstrado que tais práticas, amparadas em dispositivos das Ordenações Filipinas, reproduziam-se em diversas paragens do Império, atingindo a amplo espectro de vulnerabilidade social, que incluía crianças livres pobres, libertas e ingênuos, e assumindo feições específicas em diferentes contextos. De modo geral, não obstante, o conjunto dessas análises indica que a formalização de tais mecanismos de extração de trabalho acentua-se nas décadas finais do século, tendência verificada na cidade de São Paulo, onde o emprego de tutelas e soldadas desenhou íntimas conexões com o contexto tumultuário do encaminhamento da emancipação gradual. ${ }^{13}$ Manobras legais como a utilizada por João Antônio Dias para converter menores cativos, passíveis de serem manumitidos, em menores tutelados, submetidos ao domínio de seus "benfeitores" por longo tempo e inacessíveis à sua família pelos mecanismos da alforria, eram recorrentemente empregadas em São Paulo nas décadas finais da escravidão, recebendo novo fôlego após consumada a abolição, quando o registro de tutelas e soldadas multiplicou-se amplamente na cidade. Antes mesmo da terminação efetiva da escravidão, entretanto, a arregimentação de filhos de mulheres libertas por meio de soldadas e tutelas já indicava que as contendas em torno da emancipação implicavam a disputa do controle sobre a mão de obra de jovens e crianças empregados em diversos misteres urbanos - e esta não era uma batalha que senhores de escravos estavam dispostos a perder.

Em 1873, imbuído dos mais dignificantes espíritos da época, em nome do "desenvolvimento da liberdade que com energia se vai manifestando neste Imperio e tornando patente o jubilo pela fundação nesta Capital do Conselho Provincial Maçonico", Paulo Delfino da Fonseca concedia alforria ao menor João, filho da "escrava preta" Maria, com a ressalva de que o liberto ficasse sob sua tutela "em quanto d'ella precisar, para que possa me dirigil-o em seo beneficio”. Em 1880, possuindo "uma escrava crioula" de nome Francisca, mãe da pequena Benedicta, Francisco Antonio da Barra desistia judicialmente dos serviços da ingênua, apenas 
para, em seguida, solicitar ser nomeado tutor da mesma menor, oferecendo-se "pela amisade que tem a mesma a creal-a e educal-a". ${ }^{14}$

Sabedoras dos riscos que corriam ao assumir, para alforriar os filhos, dívidas vultuosas que potencialmente implicariam o aprofundamento de sua pauperização, e, ao mesmo tempo, conhecedoras das artimanhas utilizadas pela camada senhorial para contornar seus empreendimentos em busca de autonomia, mulheres cativas e libertas, mães de filhos ingênuos ou nascidos antes da libertação do ventre, exploravam diversas possibilidades de agência dentro de um espectro limitado de experiências de emancipação. Algumas delas, a exemplo do que ocorria às mulheres empobrecidas chefes de família de forma geral, procuravam na formação de alianças com antigos senhores ou novos patrões uma medida de acomodação que contemplasse a expectativa de preservar seus laços com os filhos e mantê-los, tanto quanto possível, próximos de seus cuidados, ainda que dentro de estreitas margens de autonomia. Em 1888, passados poucos meses da abolição, Maria, que seguia vivendo em casa de seu ex-senhor junto aos filhos, recorria a esse expediente para impedir que a filha Paula, de 14 anos, se empregasse em casa de terceiros. Os motivos que a levavam a arranjar-se aos serviços de outros patrões não são explicados, sendo tão somente resumidos no recorrente argumento da "sedução de menores", largamente utilizado por mães e empregadores de menores em disputas judiciais. Talvez Paula, entendendo-se como trabalhadora livre, julgasse melhor empregar-se longe de seu antigo senhor. Talvez, ainda, em companhia desse novo patrão, recebesse a promessa de vencimentos atraentes e melhor tratamento. Quaisquer que fossem seus motivos, no entanto, não contavam com a aquiescência de sua mãe.

Em petição encaminhada ao Juízo em junho daquele ano, oferecendo-se para o cargo de tutor dos filhos de Maria, Luis Pedroso de Oliveira, o antigo senhor e agora patrão da família, afirmava que

atendendo aos rogos da liberta Maria, que continua em sua casa delle supplicante e que quer de volta sua filha Paula, e também pela amizade que tem o supplicante aos filhos daquella liberta, vem requerer se digne V.Excia dar a esses ingenuos Paula e Jorge, filhos de Maria, tutor idoneo que zele convenientemente da educaçao e bem estar delles, de modo a impedir adquiram vicio que os torne máus elementos a sociedade.

Note-se que, evidentemente, também a Luis de Oliveira interessava manter a tutela de Paula consigo. Não era, decerto, apenas por altruísmo e 
generosidade que ele se dispunha, afinal, a zelar pelos filhos de Maria e por sua formação como "sujeitos sem vícios" e "bons elementos para a sociedade" alcunhas para a condição de trabalhadores disciplinados. Mesmo que Oliveira se aproveitasse da imagem da súplica materna a seu favor, todavia, parece amplamente possível que também Maria se beneficiasse, em alguma medida, da manutenção da proximidade com os filhos. Com frequência, mulheres libertas engajavam a si e aos filhos em sucessivos arranjos de serviços na cidade, sempre em busca de melhores condições de vida. Não há por que duvidar que a agência de trabalhadoras libertas estivesse implicada nas ações movidas por senhores ou patrões pela curatela formal dos seus filhos.

O caso de Amancia, que havia "a si se libertado" - do que se depreende que adquirira sua alforria com expedientes próprios - deixa essa dinâmica ainda mais explícita. Segundo afirmava, ao mesmo tempo que se forrara, Amancia tomara a iniciativa de "constituir peculio para libertar sua filha sem clausulas, quando foi prevenida pelo acto de sua senhora" ${ }^{15}$ Ocorria, então, que, tendo Maria, sua filha de cerca de 13 anos de idade, se tornado liberta com a condição de prestar serviços por ainda 7 anos a sua senhora, Eulália Fausta Umbelina da Silva, era agora obrigada a segui-la à província do Rio Grande do Sul, para onde se mudaria. Desconsolada, Amancia apelava ao Juízo: “A supplicante ... não se conforma com a separação de sua filha para tão longe e por tantos annos. A supplicante teme que sua filha debil e doentia não resista a mudança do clima e a novas e tão severas condições a que vai ser sujeita. Em todo caso ella a quer ter em sua companhia e a lei lhe permite".

Invocando o mesmo dispositivo da Lei 2.040 de 1871 que admitia a remissão de serviços de ingênuos, mencionado na petição de Pulcheria antes mencionada, Amancia esperava que o Juízo concedesse a Porfírio de Aguiar, "a quem actualmente serve e pediu que fisesse essa petição", a tutela e o contrato de soldada de Maria, pelo preço e nas condições mais bem avaliadas pelo juiz. Respondendo aos apelos da liberta e à proposta de tornar seu patrão também o patrão da filha, a proprietária de Maria respondia:

A supplicada, que libertou os escravos que possuia, não tem se não palavras de louvor aos que pregão pelo melhoramento das condições dos captivos; entretanto, muitos há que se aproveitão da simplicidade e ignorância dos escravos para, com a miragem da liberdade, utilizarem-se de seus serviços comoda e gratuitamente; a esses a supplicada não louva: censura. 
De fato, por volta da década de 1870 , quando o encaminhamento da questão servil e o aproveitamento do trabalho dos menores de idade ganhavam importância na agenda pública, tornara-se corrente a comparação das soldadas e tutelas ao mais vil dos cativeiros. Ainda que a analogia empregada pela proprietária - que ironicamente denunciava a "miragem" da liberdade tutelada tendo, ela própria, engajado uma menina de 13 anos a seus serviços até a vida adulta - indicasse a potencial exploração da filha uma vez tomada à tutela e à soldada, tal perspectiva não assustava à Amancia tanto quanto a possibilidade do afastamento permanente que ao fim se consumou. Aplicando o bom e velho truque de malabarismo jurídico repetido por outros senhores, Eulália Silva libertara "pura e simplesmente" Maria, sob a única condição de que fosse tutelada por seu genro. Não há qualquer surpresa ao se apurar, ao fim dos autos, que o genro, junto de sua esposa, acompanharia a sogra na mudança à província sulina. Sua tutelada, é evidente, seguiria com eles.

Prevendo empecilhos semelhantes aos enfrentados por Amancia, que obstavam a possibilidade de se manterem unidas aos filhos, e talvez calculando também o pesado fardo de dívidas assumidas com a compra de alforrias, algumas mulheres fugiam tão logo se tornavam libertas, carregando consigo rebentos que continuavam atrelados pela lei a seus antigos proprietários. Tal opção, supõe-se, não surpreenderia de todo aos proprietários de escravos da cidade de São Paulo que recebiam do interior da província amiudadas notícias de fugas em massa de cativos, durante a década de $1880 .{ }^{16}$ Nessa e na década anterior, os autos do Juízo de Órfãos registram diversas petições de busca e apreensão encaminhadas por proprietários de libertos condicionais ou contratantes de libertandos locadores de serviços que, possivelmente inspirados pelo clima de explícito enfrentamento à escravidão que tomava conta da província naqueles tempos, procuravam escapar ao controle senhorial implicado nas cláusulas de prestação de serviços e construir vidas efetivamente autônomas.

Diversos desses "fujões" eram libertas condicionais e mães de filhos ingênuos. A "preta crioula" Leocadia abandonava a casa de seu senhor, José Carlos Borba, meses após receber "liberdade com clausula de prestação de serviços por cinco annos, levando consigo uma filha, tambem preta, de dous annos e meio, ingenua, de nome Justina”. Na mesma época, Estanislao José de Oliveira Queirós procurava o juiz de órfãos para solicitar sua nomeação como tutor do menor impúbere Luiz, filho da liberta condicional Joanna que, "ultimamente fugindo-lhe de casa, não obstante a prestação de serviços que lhe deve, não tem meios de tractar do mesmo menor que corre perigo de morrer ao desamparo". 
Semelhante era a reclamação de Lina Pereira de Castro, que acusava aos libertos condicionais Victoriana e seu filho Lucio de "furtarem-se ao cumprimento de prestar-lhe serviços como são obrigados abandonando a casa da supplicante a dois mezes", levando consigo, de quebra, o ingênuo João. ${ }^{17}$ Sentindo-se ludibriados, senhores dessas mulheres acorriam às autoridades públicas solicitando, com frequência, que fossem recolhidas à Casa de Correção, e seus filhos encaminhados à tutela - de modo que preservassem o domínio sobre a parcela da mão de obra que julgavam ainda poder controlar. Naquela cidade em que a escravidão precocemente dera espaço ao influxo de muitos libertos, a influência deletéria de mulheres forras e indisciplinadas sobre seus filhos tornava-se uma preocupação de variadas proporções: era não apenas uma projeção futura sobre os perigos que assolavam o destino da mão de obra nacional e livre, a serem combatidos incutindo-se nos pequenos ingênuos e libertos a disciplina do trabalho, mas também um problema imediato que cotidianamente transtornava senhores e empregadores e demandava respostas expedientes. ${ }^{18}$

Expedientes de naturezas diversas, pactos com novos patrões, contemporizações com antigos senhores e fugas foram abordagens opostas adotadas por mulheres escravizadas no enfrentamento de um mesmo problema: a interdição da maternidade que obstava a construção de vidas familiares autônomas no pós-emancipação. Registrados nos autos do Juízo de Órfãos, esses conflitos muitas vezes transportavam tais mulheres de maneira tortuosa aos foros da Justiça, nos quais surgiam como denunciadas ou coadjuvantes das ações interpostas por empregadores e senhores. Diversos foram os casos, entretanto, de libertas que se apropriaram deliberadamente do florescimento da Justiça como campo de embates em torno da emancipação - processo que vivia seu auge nas décadas de 1870 e 1880 - para disputar direitos sobre os filhos. Amparadas pelo prestígio e a habilidade de luminares do abolicionismo nacional e paulista, levaram para as arenas judiciais as disputas que viviam cotidianamente pela atribuição de sentidos à emancipação de suas famílias. ${ }^{19}$ Nesses embates, a Lei do Ventre Livre, cujos significados eram esquadrinhados e esgrimidos nos autos do Juízo de Órfãos, tornava-se central, sendo invocada pelas partes litigantes ora como legitimadora do domínio senhorial, ora como fonte de direitos maternos.

Contraditoriamente, a despeito dos efeitos deletérios causados pela falácia da emancipação efetiva da maior parte dos ingênuos, a discussão sobre a libertação do ventre e sua culminação na lei correspondente consolidava o reconhecimento público da maternidade e da família escrava. ${ }^{20} \mathrm{O}$ tema, que evidentemente entrelaçava-se ao contexto de valorização das representações 
burguesas da maternidade correntes à época, frequentara abrasadores debates legislativos em que, apoiando-se sobre a plataforma da inviolabilidade dos laços maternos, deputados contra e a favor da libertação do ventre escravo afirmavam os prejuízos ou benefícios acarretados pela consolidação da lei. Por um lado, aqueles que se opunham à proposta escoravam-se na sacralidade da relação materna para argumentar que a libertação do ventre escravo instalaria o caos entre as famílias cativas - e, por extensão, entre a posse escrava dos senhores -, separando-as pela emancipação parcial e instigando a inveja de mães contra seus filhos libertos. Por outro, partidários da proposta argumentavam em favor de uma visão "humanitária" da escravidão que evitasse a supressão do direito inalienável de que deveriam usufruir todas as mães - qual fosse o de se manterem junto a seus filhos, sendo poupadas do sofrimento da separação. ${ }^{21}$

Ao mesmo tempo que registrava a consagração da maternidade e seus predicados inerentes como tropo das noções de civilização e modernização embutidas no lento, porém inevitável processo de desagregação da escravidão, contudo, a Lei 2.040 pontificava sobre outro tema central a que o debate acerca dos direitos e representações maternas estava inextricavelmente imbricado: o controle sobre a mão de obra egressa da escravidão. Decerto, as práticas de alforria, recorrentes por toda a história da escravidão na Colônia e no Império, ganharam novas formas com a promulgação da referida lei em 1871. Por um lado, ao romper o princípio do partus sequitur ventrem, a libertação do ventre acenava ao final inevitável do cativeiro e abria espaços para a disputa judicial da emancipação de famílias escravizadas. Por outro, ao prever um extenso período de domínio senhorial sobre os ingênuos e dispor sobre o mecanismo de locação de serviços como expediente de manumissão, a mesma lei consagrava indelevelmente a ligação entre o final do cativeiro e o estabelecimento de formas tutelares de trabalho. Era nesse entroncamento de representações maternas e políticas de encaminhamento dos sujeitos egressos da escravidão a um universo de trabalho controlado e dependente que famílias compostas por mulheres libertas e seus filhos ingênuos encontravam, ao mesmo tempo, argumentos a favor de sua emancipação e empecilhos à constituição de vidas efetivamente autônomas, após sua libertação formal.

Espelhando os contraditórios significados da Lei do Ventre Livre, os autos que registram o recurso de mães libertas à Justiça descrevem verdadeiras epopeias familiares em busca da emancipação. Rita, "parda liberta" que fora escrava de Manoel Joze Barbosa na capital, tendo se alforriado por meio de uma ação de liberdade por arbitramento encerrada pouco tempo antes, requeria em 
1880 "tomar a si, para crear devidamente" o filho Elias. ${ }^{22}$ Sua petição, amparada no já mencionado dispositivo da Lei 2.040 sobre a remissão de serviços de ingênuos menores de 8 anos de idade cujas mães eram libertas, recebia como resposta do antigo senhor, em cuja companhia vivia o filho, a breve e peremptória afirmação de que Rita não poderia "devidamente cuidar da educação do menor". Tendo Barbosa e sua senhora "criado o menor em sua casa", conforme afirmavam, solicitava sua nomeação como tutor e contratante à soldada, comprometendo-se a "mandar ensinar [Elias] a ler e escrever e aprender qualquer oficio logo que para isso mostre habilitações”. Indeferida, a postulação de Barbosa foi substituída pelo Juízo pela nomeação de Jerônimo José Mendes, patrão de Rita, como tutor e contratante do menor. Em 1884, encerrando-se o contrato de soldada celebrado entre Mendes e Elias, o primeiro relatava ao juiz de órfãos que não lhe convinha dar continuidade à tutela e seguir pagando pelos serviços do menor que se encontrava em companhia da mãe - ao que parece, não mais empregada junto ao mesmo Mendes. Não sendo renovado esse arranjo, Elias foi ainda assoldadado mais duas vezes até 1887, quando seu último contratante rescindiu o contrato para que o menor, contando então 15 anos de idade, fosse engajado nas oficinas da Estrada de Ferro. Os autos não esclarecem se Elias acompanhara a mãe nas casas em que ela se empregara, entre 1884 e 1887. A jornada rumo à autonomia havia sido longa para Rita até a metade da década - iniciada com a disputa judicial por sua alforria, continuada pela libertação do filho e seu posterior engajamento como assoldadado do patrão da mãe, alterada pela mudança de emprego sugerida pelos registros de 1884. Haveriam mãe e filho seguido juntos à procura por melhores arranjos de trabalho e condições de vida, ou teriam sido separados pela distribuição judicial da mão de obra de menores de idade?

Ainda que o estirão de emancipação de Rita e Elias tenha, de fato, se mostrado longo e algo tortuoso, outros autos apresentavam disputas ainda mais dramáticas, entre mães libertas e senhores ávidos pela manutenção do controle sobre seus filhos ingênuos. Bom exemplo é o caso em que Luiz Gama representou Vicencia e sua filha Joanna numa renhida contenda pelos direitos sobre a menor, na década de $1880 .{ }^{23}$ Liberta com pecúlio de 500 mil réis recebidos do referido abolicionista em 1879, Vicencia fora cativa do francês Jose Cazes, em cuja companhia permanecia sua filha. Mudando-se para a Corte no ano de 1880, Cazes levara consigo Joanna, que então contava, segundo Gama, menos de 8 anos de idade. Desejando reaver a filha e trazê-la de volta a São Paulo, Vicencia apelava ao Juízo reclamando o direito garantido pelo mesmo dispositivo de remissão de serviços do parágrafo $4^{\circ}$, artigo $1^{\circ}$ da Lei 2.040, 
recorrentemente invocado por mães libertas e seus advogados. Com sua habitual mordacidade, o abolicionista denunciava a imoralidade de Cazes que ilegitimamente interditava a convivência entre a filha e sua mãe "quase valuetudinaria", com mais de 50 anos de idade: "Obtida, assim, a alforria, depois de obstaculos oppostos por o Senhor que, europeu, civilizado e cidadão francez, bem sabe colher proveitos da escravidão no Brasil, pediu Vicencia a entrega de sua filha menor de 8 annos; e José Cazes fez transportar a menor para a Côrte, no intuito malvado e reprovado, de inutilizar o direito da pobre liberta que, até nisto, encontra a malevolência de seu ex-Senhor!". ${ }^{4}$

Os argumentos a favor do pleito da liberta eram legalmente sólidos, e assim o juiz do foro de São Paulo determinou a expedição de carta precatória ao Juízo da Corte, solicitando a apreensão de Joanna naquela cidade. A partir de então, instalava-se verdadeiro imbróglio burocrático entre as duas jurisdições: embasadas em tecnicalidades processuais, as autoridades responsáveis no Rio de Janeiro embargaram a petição de Luiz Gama, e a precatória do juiz de órfãos paulista voltou ao foro da cidade indeferida. Um vai e vem de novas representações, embargos e argumentações somente foi encerrado no fim daquele ano, cerca de 11 meses depois de apresentado o primeiro requerimento em nome de Vicencia, afinal deferido. O retorno de Joanna à capital da província, contudo, não encerrava as reviravoltas do projeto de emancipação encampado por sua mãe desde 1879: embora vivendo na mesma cidade, as duas seguiriam separadas, uma vez que o curador-geral de Órfãos determinara, em princípios de 1881, sem maiores alegações ou justificativas, que a menina fosse dada à tutela e soldada de terceiros. Esta, certamente, era uma realidade que Vicência partilhava com outras mulheres empobrecidas na cidade - disputar a maternidade autônoma era tarefa que não se esgotava com o próprio ingresso formal no mundo da liberdade e tampouco com o dos filhos.

Os resultados de longas batalhas judiciais, entretanto, poderiam dificultar ainda mais esse acidentado caminho quando juízes de órfãos não se convenciam dos argumentos esgrimidos em defesa do direito materno de mulheres libertas, como ocorrera à Roza Maria da Conceição em 1882. Na disputa pela tutela do filho Aragão, ingênuo, ela também contava com o auxílio de um destacado advogado abolicionista da cidade, José Fernandes Coelho, frequentador das rodas íntimas de Luiz Gama. A seu favor, Coelho apresentava petição em que informava que Roza fora escrava do capitão Eugênio Franklin de Carvalho, residente em Casa Branca, no interior da província, recebendo em 1879 liberdade "sob a condição de servir por certo tempo" ${ }^{25}$ Uma vez condicionalmente alforriada, Roza fora levada por Carvalho e sua senhora a São 
Paulo, cidade para a qual se mudaram, e onde a liberta estivera "talvez pelo espaço de dois annos servindo como escrava em diversas cazas, até que conseguiu obter a certidam junta de sua carta de liberdade, pôde por termo desta escravização, começando a alugar-se por sua conta". O alentado fim de sua escravização, que lhe permitia alugar a si própria como criada, contudo, mais uma vez não correspondia ao desfecho do empenho que precisaria empregar em seu projeto de liberdade. Conforme informava Roza na petição assinada a seu rogo, "Acontece porem que o mesmo Capitão Eugênio Franklin de Carvalho não podendo mais subjugal-a, arrebatou-lhe seo filho a cujos serviços não tem direito, e nem a supplicante annue a que fique em seo poder, e conserva-o em sua caza no Marco de Meia Légua incommunicavel para com a supplicante".

Recorrendo novamente ao expediente da remissão dos serviços de ingênuos filhos de mulheres libertas, a petição argumentava que Aragão, nascido no ano de 1873 e contando àquele momento menos de 8 anos de idade, deveria ser entregue à mãe, que não anuía em sua permanência em companhia dos antigos senhores. Vítima de "cruel illegalidade", Roza desejava reaver o filho a seus cuidados para "com o fructo de seu trabalho educa-lo". Uma certidão de batismo anexada aos autos informava, ainda, que Aragão era filho legítimo de Roza e David, nascido quando seus pais eram ainda "pretos escravos de José de Carvalho Araújo", proprietário anterior. Antes mesmo da separação do filho provocada por seu último proprietário, a família de Roza já sofrera uma possível primeira fratura: onde estaria David, seu marido e pai legítimo do ingênuo em disputa?

As informações sobre a paternidade de crianças escravizadas eram infrequentes nos registros oficiais produzidos sob o império e também sob a colônia. De fato, uma vez que a condição jurídica dos indivíduos era legada pelo ventre materno, a identificação das mães atendia suficientemente a interesses da camada senhorial e necessidades das autoridades públicas. Não obstante, interessa observar que, mesmo nas ações de liberdade e petições judiciais interpostas em nome de mulheres libertas ou escravizadas e em favor de seus filhos, a não identificação dos pais das crianças em disputa era prática amplamente dominante. Camillia Cowling sugere que tal omissão não correspondia, necessariamente, à inexistência de vínculos familiares unindo homens a seus filhos, ou à sua não participação nesses alongados processos de emancipação. Apresentar petições e interpor ações de liberdade somente em nome das mães seria, segundo a autora, estratégia que se apoiava no poder de mobilização 
concentrado na figura materna, valorizada em disputas semelhantes desde as discussões em torno da elaboração da Lei 2.040 de 1871 (Cowling, 2013, p.54).

De fato, diante do cenário apontado por estudos do tema da família escrava, e dos indícios apresentados no próprio processo, esta não é uma possibilidade a ser descartada. ${ }^{26}$ Outra possibilidade igualmente plausível, porém, seria supor que a família de Roza e David tivesse sido dividida quando da mudança para a capital - a proibição da venda em separado de membros das famílias escravas prevista no Decreto 1.695 de 1869, afinal, jamais foi observada à risca, e tampouco impedia a um proprietário manter esposas, maridos e filhos escravizados em cidades separadas, como poderia ser o caso em questão. Outrossim, ainda que os pais de Aragão tivessem vindo à capital, a realidade do trabalho de criadas alugadas impunha-se à ideia de que vivessem em uma família conforme aos termos da normatividade burguesa que se estabelecia então, um modelo estrito fundado no ideal da domesticidade e em papéis familiares rígidos e inacessíveis à população empobrecida e egressa da escravidão, de modo geral. ${ }^{27}$

Era como mulher liberta e só, portanto, que Roza parecia embrenhar-se na batalha judicial pela tutela do filho. A resposta oferecida ao Juízo pelo capitão Carvalho igualmente referia-se exclusivamente à Roza, ao mencionar a ilegitimidade de seu reclame: tudo se resumia ao fato, simples e inegável, de que ela não era em verdade mulher liberta, e sim escrava fugida. A carta de liberdade que recebera e apensara ao processo, afirmava o capitão, fora-lhe concedida por sua esposa. Pretendendo divorciar-se do marido "por desarranjo mental" e não reunindo provas para tanto, a mulher vingara-se forrando seus escravos. Sabendo que esposas não poderiam alienar bens sem o consentimento do marido, cabeça de casal, o reclamado solicitava ao juiz de órfãos que impugnasse a petição encaminhada em nome de Roza, sublinhando, numa ameaça velada, que a lei permitia-lhe ainda solicitar, caso desejasse, a captura da escrava fugida. Concluindo suas considerações, pedia respeitosamente "proteção das authoridades ... contra o maniqueismo de certos abolicionistas que primão nesta Capital pelo arrogo que tem sem mais respeito algum pelas leis desse pays". Acolhendo seus argumentos, o juiz de órfãos deliberava contrariamente aos interesses de mãe e filho.

Bem ou malsucedidas, longas narrativas de emancipação coletiva como estas chegavam com frequência aos autos do Juízo de Órfãos de São Paulo. Representadas por advogados que traduziam sua busca pela libertação e a autonomia familiar em disputas frequentemente retóricas, que esmiuçavam os sentidos possíveis da Lei do Ventre Livre - notadamente do dispositivo de 
remissão de serviços de ingênuos encontrado em seu artigo primeiro, constantemente reivindicado -, mães libertas surgiam, em geral, escamoteadas pela parafernália judicial: petições, arrogos e escrivães, despachos, juntadas e a exegese das leis pareciam sobrepor-se às suas palavras. Eram precisamente essas mulheres, no entanto, que capitaneavam com enorme fôlego empreendimentos familiares que envolviam diversas etapas e grande comprometimento: conquistar a própria liberdade; assegurar o direito sobre os filhos; arranjar sobrevivências como famílias libertas; lidar com a imposição de tutelas e soldadas que causavam novas fissuras em seus vínculos familiares. Aliando sua pertinácia, a firme convicção de serem, elas também, portadoras de "direitos maternos sagrados" forjados com base na moldura da feminilidade burguesa, e ainda o apoio de ilustres figuras do abolicionismo, diversas mães de ingênuos tinham seus pleitos acolhidos pelo Juízo de Órfãos. ${ }^{28}$ Outras, de menos sorte, viam suas pretensões serem rechaçadas nas arenas da justiça formal. Talvez, a exemplo do que faziam tantas outras libertas, apelassem depois disso a medidas mais extremas como a fuga.

Desse modo, mesmo que a justiça lhes concedesse o direito de retirar os filhos do poder senhorial e retomá-los a seus cuidados, a construção de vidas familiares autônomas apresentava-lhes cotidianamente novos estorvos e obstruções. A partir de 1888, imediatamente após a abolição, o recurso de senhores expropriados à tutela e a contratação formal de menores egressos da escravidão cresceram enormemente na cidade. As plataformas sobre as quais esses senhores apresentavam suas demandas já não poderiam mais ser as leis e os direitos costumeiros reguladores da escravidão que, até então, condensava as hierarquias sociais e conferia amplos poderes à camada proprietária. A ausência dessa instituição implicava a elaboração de novos códigos de dominação que garantissem o controle sobre a mão de obra perdida à emancipação. Nessa empreitada, pleiteantes à tutela e à soldada dos filhos de mães libertas socorriam-se nas representações da maternidade inadequada das mulheres empobrecidas, adicionando-lhes traços distintivos que fariam das mulheres egressas da escravidão o símbolo definitivo das "mães impróprias" e incapazes de bem educar os filhos, futuro da nação.

\section{REFERÊNCIAS}

ABREU, Martha. Slave Mothers and Freed Children: Emancipation and Female Space in Debates on the 'Free Womb' Law, Rio de Janeiro, 1871. Journal of Latin 
American Studies, Cambridge, UK: Cambridge University Press, v.28, n.3, p.567580, 1996.

ALANIZ, Anna Gicelle G. Ingênuos e libertos: estratégias de sobrevivência familiar em épocas de transição (1871-1895). Campinas: CMU/Unicamp, 1997.

ALMEIDA, Angela Mendes de. Família e modernidade: o pensamento jurídico brasileiro no século XIX. São Paulo: Porto Calendário, 1999.

ARIZA, Marília B. de Araújo. Bad mothers, labouring children: emancipation, tutelage and motherhood in São Paulo over the last decades of the $19^{\text {th }}$ century. Slavery \& Abolition, Abingdon, UK: Taylor and Francis, v.38, n.2, p.408-424, 2017b.

Mães infames, rebentos venturosos: mulheres e crianças, trabalho e emancipação em São Paulo (século XIX). Tese (Doutorado em História Social) - Faculdade de Filosofia, Letras e Ciências Humanas (FFLCH), Universidade de São Paulo (USP). São Paulo, 2017a.

. O ofício da liberdade: libertandos locadores de serviços em São Paulo e Campinas (1830-1888). São Paulo: Alameda, 2014.

AZEVEDO, Elciene. Orfeu de carapinha: a trajetória de Luiz Gama na imperial cidade de São Paulo. Campinas: Ed. Unicamp, 2005.

AZEVEDO, Gislane Campos. De Sebastianas e Geovannis: o universo do menor nos processos dos juízes de órfãos da cidade de São Paulo (1871-1917). Dissertação (Mestrado em História) - Faculdade de Ciências Sociais, Pontifícia Universidade Católica (PUC-SP). São Paulo, 1995.

BERTIN, Enidelce. Alforrias na São Paulo do século XIX: liberdade e dominação. São Paulo: Humanitas, 2004.

CASTILHO, Celso T.; COWLING, Camillia. Bancando a liberdade, popularizando a política: abolicionismo e fundos locais de emancipação na década de 1880 no Brasil. Afro-Ásia, Salvador: UFBA, n.47, p.161-197, 2013.

COWLING, Camillia. Conceiving Freedom: Women of Color, Gender and the Abolition of Slavery in Havana and Rio de Janeiro. Chapel Hill, NC, USA: The University of North Carolina Press, 2013.

COWLING, Camillia; MACHADO, Maria Helena; PATON, Diana; WEST, Emily (Org.) Special Issue: Mothering Slaves: Motherhood, Childlessness and the Care of Children in Atlantic Slaves Societies. Slavery \& Abolition, Abingdon, UK: Taylor and Francis, v.38, n.2, June 2017.

FLORENTINO, Manolo; GÓES, Roberto. A Paz nas Senzalas: família escrava e tráfico atlântico, 1790-1850. Rio de Janeiro: Civilização Brasileira, 1997.

FONSECA, Marcus Vinícius. A educação dos negros: uma nova face do processo de abolição da escravidão no Brasil. Bragança Paulista, SP: Edusf, 2002.

GEREMIAS, Patrícia Ramos. Ser "ingênuo" em Desterro/SC: a lei de 1871, o vínculo tutelar e a luta pela manutenção dos laços familiares das populações de origem 
africana (1871-1889). Dissertação (Mestrado em História) - Instituto de Ciências Humanas e Filosofia, Universidade Federal Fluminense (UFF). Niterói, 2005.

HARTMAN, Saidiya. Seduction and the ruses of power. Callaloo, Baltimore, MD: Johns Hopkins University Press, v.19, n.2, p.537-560, 1996.

KING, Elma. "Suffer with Them Till Death": Slave Women and Their Children in the Nineteenth-Century America. In: GASPAR, David Barry; HINE, Darlene Clarke (Org.) More than Chattel: Black Women and Slavery in the Americas. Bloomington and Indianapolis, IN, USA: Indiana University Press, 1996. p.147-168.

LIMA, Henrique Espada. Sob o domínio da precariedade: escravidão e os significados da liberdade no século XIX. Topoi, Rio de Janeiro: UFRJ, v.6, n.11, p.289-326, 2005. . Trabalho e lei para os libertos de Santa Catarina no século XIX: arranjos e contratos entre a autonomia e a domesticidade. Cadernos AEL, Campinas: Unicamp, v.14, n.26, 2009.

MACHADO, Maria Helena P. T. O Plano e o pânico: os movimentos sociais na década da abolição. Rio de Janeiro: Ed. UFRJ; São Paulo: Edusp, 1994.

"Teremos grandes desastres, se não houver providências enérgicas e imediatas": a rebeldia dos escravos e a abolição da escravidão. In: SALLES, Ricardo; GRINBERG, Keila. O Brasil Imperial: 1870-1889. v.III. Rio de Janeiro: Civilização Brasileira, 2009.

MEZNAR, Joan. Orphans and the transition from slave to free labor in the Northeast Brazil: the case of Campinas Grande, 1850-1888. Journal of Social History, New York: Oxford University Press, v.27, n.3, p.499-515, 1994.

MORGAN, Jennifer L. Laboring Women: reproduction and Gender in New World Slavery. Philadelphia, PN, USA: University of Pennsylvania Press, 2004.

MOUTINHO, Laura. Razão, "cor" e desejo: uma análise comparativa sobre relacionamentos "inter-raciais" no Brasil e na África do Sul. São Paulo: Unesp, 2004. p.51-103.

OTSUKA, Alexandre Ferro. Antonio Bento: discurso e prática abolicionista na São Paulo da década de 1880. Dissertação (Mestrado em História Social) - Faculdade de Filosofia, Letras e Ciências Humanas (FFLCH), Universidade de São Paulo (USP). São Paulo, 2016.

PAPALI, Maria Aparecida C. R. Escravos, órfãos e libertos: a construção da liberdade em Taubaté (1871-1895). São Paulo: Annablume; Fapesp, 2003.

PINHEIRO, Luciana de Araújo. A civilização do Brasil através da infância: propostas e ações voltadas às crianças pobres no final do Império (1879-1889). Dissertação (Mestrado em História Moderna e Contemporânea) - Instituto de Ciências Humanas e Filosofia, Universidade Federal Fluminense (UFF). Niterói, 2003.

REIS, Isabel Cristina F. dos. Histórias de vida familiar e afetiva de escravos na Bahia do século XIX. Salvador: Centro de Estudos Baianos da UFBA, 2001. 
REIS, Isabel Cristina F. dos. "Uma negra que fugio, e consta que já tem dous filhos": fuga e família entre escravos na Bahia. Afro-Ásia, Salvador: UFBA, n.23, p.27-46, 1999.

SCHWARTZ, Marie Jenkins. Birthing a Slave: Motherhood and Medicine in the Antebellum South. Cambridge, Mass: Harvard University Press, 2009.

SIQUEIRA, Lucília. As crianças pobres nas franjas da economia cafeeira: os contratos de órfãos em Socorro/SP na década de 1880. Revista Brasileira de História e Ciências Sociais, Santa Vitória do Palmar, RS: Furg, v.2, n.4, p.22-34, 2010.

SLENES, Robert W. Na senzala, uma flor: esperanças e recordações na formação da família escrava - Brasil Sudeste, século XIX. Rio de Janeiro: Nova Fronteira, 1999.

SLENES, Robert W.; FARIA, Scheila de Castro. Família escrava e trabalho. Tempo, Rio de Janeiro: UFF, v.6, n.3, p.37-47, 1998.

SOUSA, Ione Celeste de J. "Porque um menor não deve ficar exposto à ociosidade, origem de todos os vícios": Tutelas e Soldadas e o trabalho de Ingênuos na Bahia, 1870 a 1900. In: MACHADO, Maria Helena P. T.; CASTILHO, Celso Thomas (Org.) Tornando-se livre: agentes históricos e lutas sociais no processo de abolição. São Paulo: Edusp, 2015. p.189-211.

TEIXEIRA, Heloísa Maria. A não infância: crianças como mão de obra em Mariana (1850-1900). Tese (Doutorado em História Econômica) - Faculdade de Filosofia, Letras e Ciências Humanas (FFLCH), Universidade de São Paulo (USP). São Paulo, 2007.

TELLES, Lorena F. da Silva. Libertas entre sobrados: mulheres negras e trabalho doméstico em São Paulo (1880-1920). São Paulo: Alameda, 2014.

URRUZOLA, Patrícia. Ex-proprietários nos dias seguintes à abolição: práticas e discursos de "escravização" de ingênuos (Rio de Janeiro, 1888). História, Histórias, Brasília: UnB, v.4, n.8, p.155-172, 2016.

WALLACE-SANDERS, Kimberly. Mammy: a century of race, gender and southern memory. Ann Arbor, MI, USA: University of Michigan Press, 2008.

ZERO, Arethuza Helena. O preço da liberdade: caminhos da infância tutelada - Rio Claro (1871-1888). Dissertação (Mestrado em História) - Instituto de Filosofia e Ciências Humanas (IFCH), Universidade Estadual de Campinas (Unicamp). Campinas, 2004.

\section{NOTAS}

${ }^{1}$ Este artigo corresponde a parte das discussões apresentadas em minha tese de doutoramento, defendida em 2017 e realizada com financiamento da Fundação de Amparo à Pesquisa do Estado de São Paulo (Processo Fapesp 2012/20612-8), ARIZA, 2017a.

${ }^{2}$ Cf. Primeiro Cartório de Notas da Capital, Livro 85, F27, 1875. 
${ }^{3}$ O Relatório da Província de 1886, citado por Lorena Feres da Silva Telles, apontava que os salários de empregados domésticos e cozinheiros deveriam variar entre 20 e 40 mil réis e entre 25 e 60 mil réis, respectivamente (TELLES, 2014, p.121; ARIZA, 2014, p.179).

${ }^{4}$ A esse respeito, ver: LIMA, 2005 e 2009; ARIZA, 2014.

${ }^{5}$ No caso da historiografia sobre os Estados Unidos e o Caribe (sobretudo em sua porção britânica), pode-se dizer que os estudos dedicados às interseções entre escravidão e maternidade há algum tempo vêm constituindo importante acúmulo (ver: MORGAN, 2004; WALLACE-SANDERS, 2008; SCHWARTZ, 2009). Dois dossiês, publicados em 2017, reúnem novos estudos sobre o tema em diversas áreas escravistas das Américas, incluindo-se o Brasil: COWLING et al., 2017.

${ }^{6}$ Esse padrão pode ser observado também nas negociações de alforria descritas por Cowling e ocorridas no Rio de Janeiro e em Havana (COWLING, 2013).

${ }^{7}$ Sobre os fundos de emancipação, que privilegiavam a libertação de mulheres com filhos, ver: CASTILHO; COWLING, 2013.

${ }^{8}$ Cf. APESP - Juízo de Órfãos: Autos de liberdade, lata C05356, doc. 4, 1886; Autos de contrato, lata C05358, doc. 21, 1886; Autos de pecúlio, lata C05422, doc. 44, 1887.

${ }^{9}$ A prevalência de mulheres entre alforriados é apontada por estudos que assumem diferentes abordagens teóricas com relação ao significado das práticas de manumissão. Em São Paulo, o tema é explorado por Enidelce Bertin, cujas interpretações este artigo subscreve (BERTIN, 2004).

${ }^{10}$ A matriz mais notável dessa interpretação é, certamente, o pensamento freyreano consagrador da narrativa da escravidão docilizada, que tem em Casa-grande \& senzala seu maior representante. O conteúdo "afetivo" de relações de exploração tem sido alvo de reflexões e questionamentos interessantes de pesquisadores da escravidão. No que tange aos estudos sobre a alforria, é ainda persistente a referência à "agência" de mulheres escravizadas que construíam acessos à liberdade formal por meio de relações que resultavam na produção de filhos ilegítimos de seus senhores. Críticas à reificação da mulher negra e mestiça como símbolo de lascívia, sedução e hipersexualização escamoteada por essas interpretações sobre a agência escrava podem ser encontradas em: HARTMAN, 1996; MOUTINHO, 2004, p.51-103.

${ }^{11}$ Cf. APESP - Juízo de Órfãos, Autos de diligência, lata C05360, doc. 23, 1883.

${ }^{12}$ Sobre os parâmetros jurídicos que regulavam a tutela no século XIX, ver: ALMEIDA, 1999. Diversos dispositivos das Ordenações Filipinas referem-se à orfandade como condição que englobava os filhos ilegítimos ou de pais falecidos até que completassem 25 anos. Até atingirem esta idade, os órfãos eram passíveis de serem tutelados. Cf. Ordenações Filipinas, Livro 1º, Título 138, Parágrafos 19 a 21. Disponível em: http://www1.ci.uc.pt/ihti/ proj/filipinas/l1p212.htm; acesso em: 17 abr. 2017. O Código Criminal imperial, datado de 1830, estabelecia a maioridade penal aos 21 anos, e foi essa a idade-limite adotada pelas leis orfanológicas, a despeito de serem legatárias das Ordenações Filipinas.

${ }^{13}$ Vários são os estudos que dão conta dos usos de tutelas e soldadas na arregimentação da 
mão de obra de crianças empobrecidas e egressas da escravidão, como é o caso dos trabalhos de Maria Aparecida Papali e Ione Celeste de Souza, que sublinham a utilização desses mecanismos na continuada dominação de ingênuos; e de Gislene Azevedo, que pioneiramente abordou esse emprego no aliciamento de crianças empobrecidas, sobretudo livres, na cidade de São Paulo. Ver, entre outros: MEZNAR, 1994; AZEVEDO, 1995; ALANIZ, 1997; PAPALI, 2003; PINHEIRO, 2003; GEREMIAS, 2005; ZERO, 2004; TEIXEIRA, 2007; SIQUEIRA, 2010; SOUSA, 2015. A bibliografia sobre o tema é abordada extensiva e detidamente em minha tese de doutoramento, na qual discuto as interpretações usuais a respeito do acúmulo de tutelas e soldadas formalizadas a partir de 1870 (ARIZA, 2017a).

${ }^{14}$ Cf. APESP - Tribunal de Justiça de São Paulo, lote 201006004045, Contrato a soldada, 1873; APESP - Juízo de Órfãos, Autos de liberdade, lata C05355, doc. 15, 1880.

${ }^{15}$ Cf. APESP - Juízo de Órfãos, Autos de diligência, lata C05360, doc. 20, 1883.

${ }^{16}$ Sobre as crescentes preocupações trazidas pelas fugas em massa de escravos nessa década, ver: MACHADO, 1994 e 2009.

${ }^{17}$ Cf. APESP - Juízo de Órfãos: Autos de diligência, lata C05360, doc. 32, 1884; Juízo de Órfãos, Autos de tutoria, lata C05455, doc. 9047, 1884; Autos de diligência, lata C05360, doc. $30,1884$.

${ }^{18}$ As fugas de famílias escravizadas - diversas delas compostas por mães e filhos pequenos ou mulheres grávidas - e a importância da preservação dos vínculos familiares para sujeitos cativos que buscavam ativamente sua autonomia são discutidas por Isabel Reis (REIS, 1999). Wilma King aborda as fugas de mulheres escravizadas e seus filhos (KING, 1996).

${ }^{19}$ Sobre a militância abolicionista de advogados paulistas, ver: AZEVEDO, 2005; OTSUKA, 2016.

${ }^{20}$ Sobre o massivo número de ingênuos não libertados por seus senhores em troca da indenização prevista no artigo $1^{\circ}$, parágrafo $1^{\circ}$ da Lei 2.040, há interessantes comentários em FONSECA, 2002. Patrícia Urruzola indica que, no Rio de Janeiro, clubes e luminares do abolicionismo local, como José do Patrocínio, igualmente denunciavam os abusos praticados por ex-senhores em ingênuos que os tomavam à tutela (URRUZOLA, 2016).

${ }^{21}$ Foi Martha Abreu quem primeiro chamou a atenção para a importância de se avaliarem os debates legislativos em torno da Lei do Ventre Livre, nos quais a maternidade escrava tornava-se plataforma para argumentos contrários e favoráveis à proposta (ABREU, 1996).

${ }^{22}$ Cf. APESP - Tribunal de Justiça de São Paulo, lote 201006003491, Contrato a soldada, 1880-1887.

${ }^{23}$ Cf. APESP - Juízo de Órfãos, Autos de diligência, lata C05360, doc. 9, 1880.

${ }^{24}$ Cf. APESP - Juízo de Órfãos, Autos de diligência, lata C05360, doc. 9, 1880, grifo no original. A participação de mulheres mais velhas em disputas judiciais pela emancipação dos filhos - muitos dos quais não mais menores de idade - pouco aparece entre os autos do Juízo de Órfãos da Capital. Sua presença parece ser bastante mais frequente nos arquivos pesquisados por Cowling no Rio de Janeiro e em Havana (COWLING, 2013). 
${ }^{25}$ Cf. APESP - Juízo de Órfãos, Autos de diligência, lata C05360, doc. 15, 1882.

${ }^{26}$ Sobre a constituição de vínculos familiares estáveis sob o cativeiro, são referências: SLENES, 1999; FLORENTINO; GÓES, 1997; REIS, 2001. A formação da família escrava nas cidades era impactada pelo fato de as posses escravas urbanas serem, em geral, menores e mais instáveis do que aquelas das áreas de plantation. As posses de maior proporção, como indicam Slenes e Faria, eram em geral destinadas ao aluguel, algo que, como no caso em tela, dificultava a manutenção dos vínculos familiares em núcleos domésticos estáveis (SLENES; FARIA, 1998).

${ }^{27}$ Uma discussão mais aprofundada sobre a emergência e circulação de modelos familiares burgueses nos discursos higienistas, médicos e burgueses se encontra em ARIZA, 2017b.

${ }^{28}$ As representações e contrarrepresentações da maternidade forjadas em moldes burgueses tiveram lugar central nas disputas de mulheres libertas pela tutela dos filhos nas décadas finais da escravidão, como demonstrado em ARIZA, 2017b. 